\title{
Мотив читања на плакатима с краја 19. века у Дигиталним збиркама Њујоршке јавне библиотеке
}

\author{
Јелена Јовин \\ Библиотека Матице српске, Нови Сад \\ jovinj@bms.ns.ac.rs
}

\begin{abstract}
Сажетак
У ери дигитализације, све већа количина граће постаје доступна корисницима на вебу. Сходно томе, за потребе прикупљања материјала током приређивања изложбе, припреме предавања, истраживања историје неког народа, живота одрећеног сликара, писања блога или постовања твита, неопходне илустрације, фотографије или рукописи могу се потражити на неком од портала са дигитализованом грађом попут Еуропеане, Дигиталне јавне библиотеке Америке и многих других. Овај рад има за циљ да прикаже ток претраживања одабране теме и грађе мотива читања на плакатима на порталу Дигиталних збирки Њујоршке јавне библиотеке, с обзиром на то да је део грађе јавно доступан. Поред многобројних могућности коришћења и дељења грађе за кориснике портала, указано је и на потешкоће у њеном претраживању. Сврха рада је да се из угла библиотекара као корисника, читаоцима приближи функционисање једног портала са дигитализованом грађом, укаже на проблематику њене обраде, видљивости и досупности, као и да подстакне библиотекаре да осмисле идеје и решења за израду што привлачнијих, прегледнијих и кориснику прилагођених портала.
\end{abstract}

Кључне речи: Њујоршка јавна библиотека (New York Public Library), портал, дигитализована грађа, јавна доступност, претраживање, плакат, читање, класификација, метаподаци, дељење, прегледност, прилагођеност кориснику

\begin{abstract}
Увод
Упркос савременом феномену присуства све веће количине јавно доступне дигитализоване грађе на интернету, пред кориснике се намећу нови изазови попут (не)лакоће њеног претраживања и проналажења. Многи истраживачи, предавачи, уметници, архивисти, издавачи, библиотекари и други корисници додатно се суочавају са питањем права коришћења, репродуковања и могућностима њеног дељења. Ауторка рада дотиче се ових аспеката коришћења грађе представљајући конкретан пример процеса и проблематике претраживања грађе на одабраном порталу.

Непосредан повод за истраживање био је пост Њујоршке јавне библиотеке на Инстаграму у којем је промовисан онлајн билтен са препорукама за читање. У њему је приказана насловна страница часописа Harper's Magazine, објављеног 1897. године, са илустрацијом Едварда Пенфилда (енг. Edward Penfield), 1 чији детаљи су навели ауторку да истражи мотив читања на плакатима у Дигиталним збиркама ове библиотеке (Сл. 1). Под мотивом читања подразумева се визуелно представљена људска фигура, некад и више, у стојећем или седећем положају, са публикацијом у рукама и погледом упереним ка њој. Заправо, ради се о врло занимљивој, али технички захтевној потрази за илустрацијама субјеката који посматрају, односно читају публикацију, најчешће у облику новина или књиге.
\end{abstract}

\footnotetext{
1 Амерички илустратор и уметнички уредник часописа Harper's, препознатљив по једноставности облика и сведеном колориту на дизајнерским решењима насловница, плаката, календара и илустрацијама прича и чланака. Његови ликовни радови оставили су значајан траг у историји америчке илустрације, плаката и графичког дизајна.
} 
За почетак биће приказан сам контекст у којем се одвија истраживање, односно описане карактеристике портала са дигитализованом грађом и могућностима које он корисницима пружа.

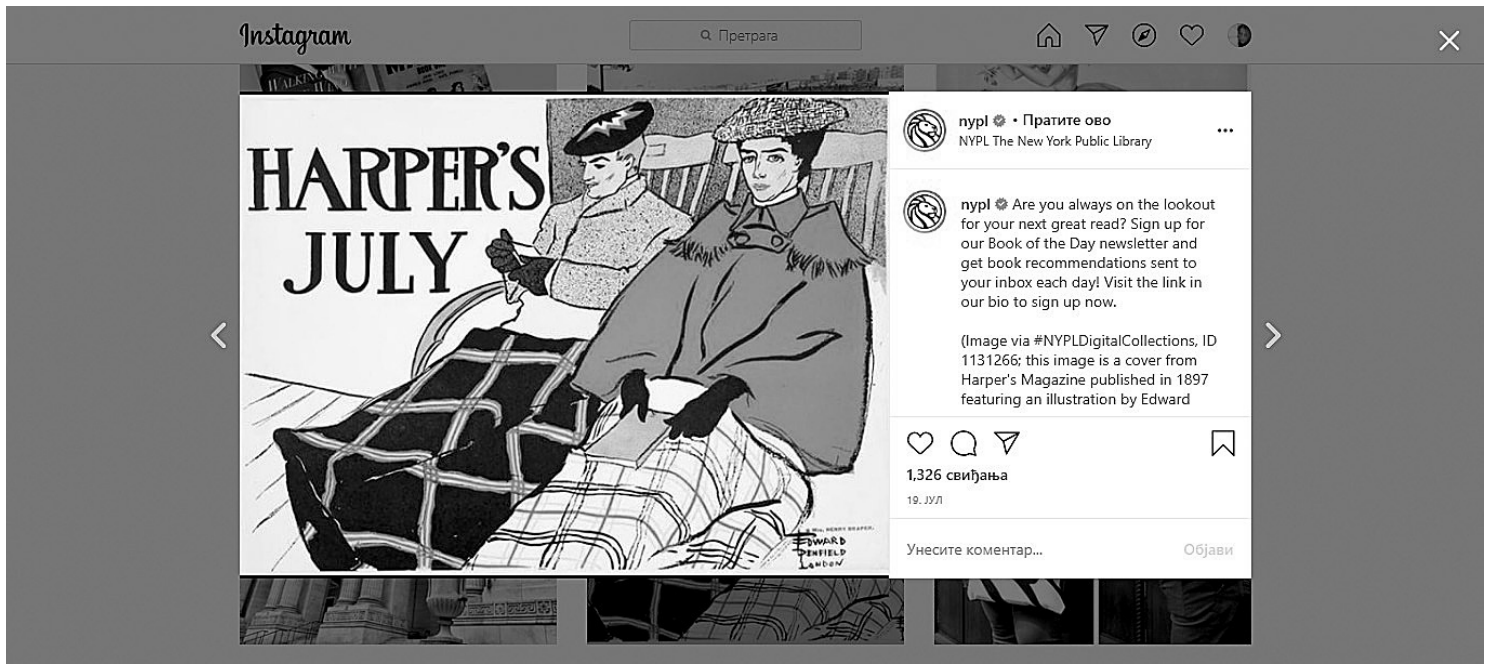

Слика 1. Пост Њујоршке јавне библиотеке на Ннстаграму са тагом \#NYPLDigitalCollections и ID бројем плаката ${ }^{2}$

\section{Дигиталне збирке Њујоршке јавне библиотеке}

„Доступност је важна јер желимо да људи користе наше збирке како би обогатили свој и животе других. Верујем да је то разлог што грађу прво сакупљамо и обрађујемо, систематизујемо по вековима и деценијама, а затим вршимо дигитализацију."

Џош Хадро

Откако је пуштена у јавност, јануара 2015. године, платформа под називом Дигиталне збирке Њујоршке јавне библиотеке ${ }^{4}$ непрестано увећава број јединица грађе. Тренутно их броји чак 898.802, које представљају само део разноликог материјала из богатих збирки Библиотеке: књиге, видео-записе, географске карте, рукописе, илустрације, фотографије и друго. Поред статичних слика, на веб-сајту се налази и аудио, видео и текстуална грађа, као и интерактивни садржаји попут различитих експеримената: анимација фотографија, ${ }^{5}$ идентификовање зграда и других детаља на старим географским картама Њујорка, ${ }^{6}$ игра истраживања планова

\footnotetext{
2 The New York Public Library, "Are you always on the lookout for your next great read?", Instagram, 15. 9. 2020, https://www.instagram.com/p/CC04QBm/W3s/.

3 Josh Hadro, "Manufacturing Impact: Why We Digitize", New York Public Library, November 6, 2017, preuzeto 24. 7. 2020, https:// www.nypl.org/blog/2017/11/06/manufacturing-impact-digitize.

${ }^{4}$ The New York Public Library, "Digital Collections", preuzeto 24. 7. 2020, https://digitalcollections.nypl.org/.

${ }^{5}$ Stereogranimator, preuzeto 2. 8. 2020, http://stereo.nypl.org/.

${ }^{6}$ The New York Public Library, Building inspector. Kill time. Make history, preuzeto 2. 8. 2020, http://buildinginspector.nypl.org/.
} 
Јовин J. „Мотив читања на плакатима с краја 19. века у Дигиталним збиркама Њујоршке јавне библиотеке“, 93-102

грандиозних станова у овом граду с почетка 20. века и многи други. ${ }^{7}$ Ту је и алатка за визуелно прегледање 187.000 дигиталних фотографија високе резолуције, илустрација и докумената из јавног домена, која омогућава корисницима да их истражују по временској одредници, жанру, збиркама или боји. ${ }^{8}$ Требало би споменути и могућност за креативно коришћење фотографија високе резолуције на папиру, муралима, тканинама. ${ }^{9}$ На крају, важно је истаћи да иза свих ових иновација и апликација стоје тимови библиотекара и кустоса у сарадњи са одељењима за дигитализацију. ${ }^{10}$ Што се тиче циљева ове платформе, према мишљењу Џоша Хадра, она постоји да би дигитализованој грађи пружила одговарајуће онлајн окружење и инспирисала људе да је користе и репродукују, уче и стварају нова дела. ${ }^{11}$

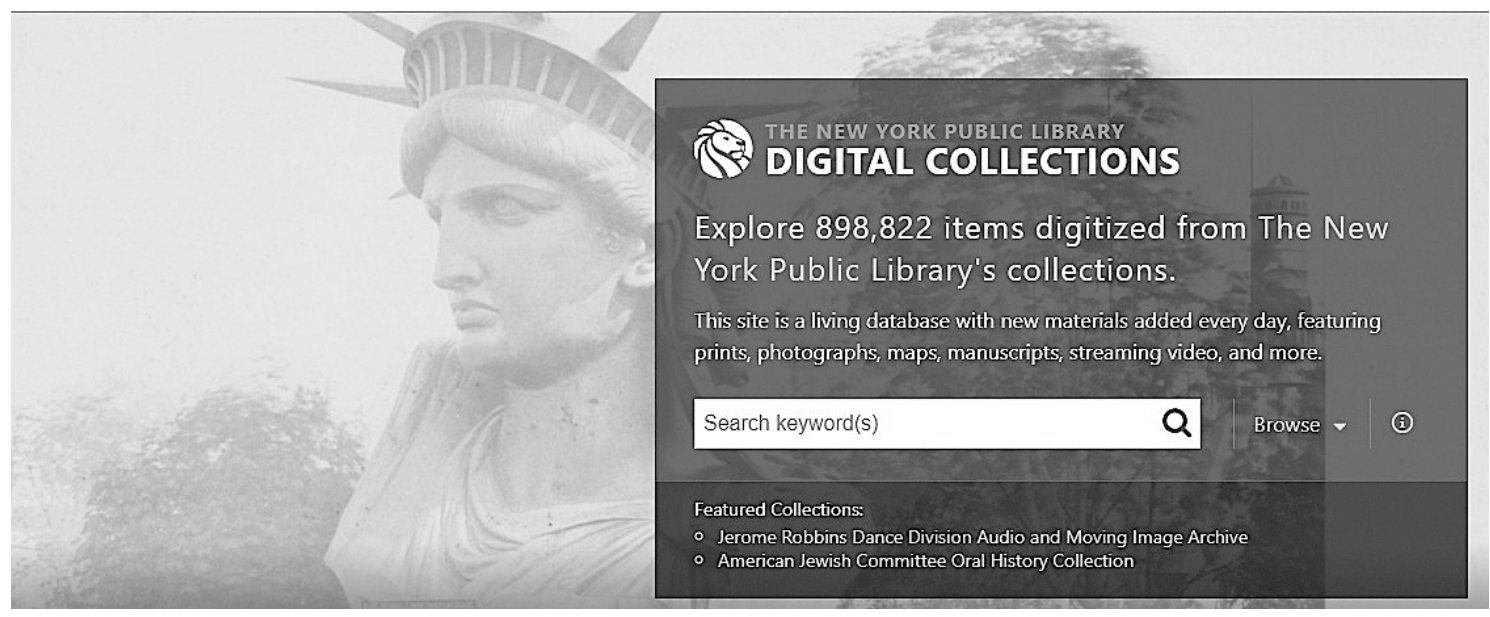

Слика 2. Претраживач Дигиталних збирки Њујоршке јавне библиотеке

\section{Претраживање дигиталних збирки}

Поступак претраживања је кључни моменат у истраживању грађе и за кориснике је детаљно објашњен и илустрован у уводном чланку блога на веб-сајту Библиотеке, ${ }^{12}$ до којег води симбол „і" (енг. information), смештен поред претраживача на приступној веб-страници (Сл. 2). Јединице на веб-сајту портала су тако организоване да их је могуће претраживати на три нивоа: по јединици грађе, збирци, или одељењу којем припадају. Одељења, њих 24, су опет организационе јединице библиотеке чија је грађа представљена (нпр. Бергова збирка енглеске и америчке књижевности, ${ }^{13}$ Одељење за позориште Билија Роуза, ${ }^{14}$ Одељење за плес Џерома

\footnotetext{
${ }^{7}$ Mauricio Giraldo, remix by, "Mansion Maniac", Apartment Houses of the Metropolis collection, preuzeto 24. 7. 2020, http://publicdomain.nypl.org/mansion-maniac/.

8 Brian Foo, remix by, A public domain of NYPL Labs, preuzeto 2. 8. 2020, http://publicdomain.nypl.org/pd-visualization/.

9 Lauren Lampasone, "\#nyplremix: Get Creative With the Public Domain", New York Public Library, January 6th 2016, preuzeto 24. 7 2020, https://www.nypl.org/blog/2015/01/06/creativity-public-domain.

10 NYPL Technology Group, NYPL Labs.

11 Josh Hadro, "NYPL Digital Collections Platform: An Introduction", New York Public Library, January 21st 2015, preuzeto 2. 8. 2020, https://www.nypl.org/blog/2015/01/21/digital-collections-platform-intro.

12 Josh Hadro, "NYPL Digital Collections Platform: An Introduction", New York Public Library, January 21st 2015, preuzeto 2. 8. 2020, https://www.nypl.org/blog/2015/01/21/digital-collections-platform-intro.

13 Енг. Berg Collection of English and American Literature.

${ }^{14}$ Eнг. Billy Rose Theatre Division.
} 
Робинса ${ }^{15}$ и др.). На веб-страници сваког одељења постоји кратак опис са линком ка детаљнијим информацијама, као и трака са недавно дигитализованим јединицама и збиркама. Свака збирка, поред кратког описа, има део са различитим филтерима: јавна доступност, тема, име, збирка, жанр, одељење, тип грађе и временски период. Наведене категорије су заправо метаподаци и претраживи су. Унутар сваке збирке грађа може да се сортира по наслову, датуму креирања или датуму дигитализације.

Претрага мотива читања започета је на нивоу збирки коришћењем појма плакат и филтера за јавну доступност, јер постоји потреба за њиховим приказивањем. Резултати су указали на четири збирке: Мајстори плаката, ${ }^{16}$ Плакати америчких књига, ${ }^{17}$ Плакати Едварда Пенфилда ${ }^{18}$ и Новински плакати. ${ }^{19}$ Требало би напоменути да претрага без филтера за јавну доступност постаје богатија збирком под називом Плакати уметника, ${ }^{20}$ која је у ствари видљива, али не и доступна за јавну употребу.

У даљем тексту биће дат детаљнији опис збирки, указано на њихове сличности и разлике, али и на могућности и мањкавости процеса претраживања, прегледања и коришћења грађе.

\section{Информације, метаподаци и опције у дигиталном окружењу збирки}

Оно што је свим збиркама заједничко је да припадају истом Одељењу уметности, штампе и фотографија Мириам и Ире Д. Валах: збирка уметности и архитектуре. ${ }^{21}$ Три збирке: Плакати америчких књига, Плакати Едварда Пенфилда и Новински плакати, имају идентичан кратак опис збирке са биографским и историјским подацима: „Појава уметничког плаката у Америци може се пратити објављивањем рекламног плаката Едварда Пенфилда у издању Harper's из марта 1893. године. За разлику од ранијих рекламних плаката, Пенфилдов рад је представио такав графички наратив у коме је текст био споредан. На овај начин, а касније кроз рад значајних уметника попут Пенфилда, Вила Бредлија и Етел Рид, постер се винуо из домена комерцијалне уметности на један виши степен."22

Још битније је указати на разлике, односно специфичности информација и опција унутар дигиталног окружења сваке збирке које су се појавиле у току процеса претраживања. То су значајност употребе филтера, опција за сортирање грађе, (не)постојање различитих категорија (метаподаци) којима су описани плакати и начин приказивања грађе. На примеру веб-странице једног дигиталног плаката биће споменуте опције за преузимање, дељење и цитирање.

У првој Збирии йлакайа Egварgа Пенфилgа налази се укупно 113 јавно доступних плаката које је Едвард Пенфилд (1866-1925) цртао већином за новинска издања издавачке куће Harper's у Њујорку 1890-1907. године. Плакати су сакупљени и смештени у фонду Њујоршке јавне библиотеке 1931. године.

Претраживање грађе унутар ове збирке започето је коришћењем филтера јавна доступност, а затим настављено филтрирањем по теми (Сл. 3). Постоје чак 93 тематске категорије,

\footnotetext{
15 Енг. Jerome Robbins Dance Division.

16 Франц. Les Maitres de L'affiche.

17 Енг. American book posters.

18 Eнг. Posters by Edward Penfield.

${ }^{19}$ Енг. Newspapers posters.

20 Енг. Posters: arranged by artists. Ова збирка броји чак 865 јединица, од којих је само 5 јавно доступно. Припада истом одељењу као и остале описане збирке. Оригинални плакати су постављени и увезани у Њујоршкој јавној библиотеци 1935. године. У области теме ова збирка има велики број категорија, а по теми иишање пронађено је 19 плаката. Област аутора је такође богата именима. Према насловима плаката са темом иишање, уочљива је њихова разноликост у многобројним периодичним публикацијама као што су: Scribner's, Overland Monthly, The bachelor of arts, The Pocket Magazine, Collier's, The New York Sunday Journal, The bookman, Outing итд. С озиром на то да претраживање по теми није прецизно, потребно је прегледати све јединице без филтера.

${ }^{21}$ Енг. The Miriam and Ira D. Wallach Division of Art, Prints and Photographs: Art \& Architecture Collection.

22 The New York Public Library, "Digital Collections: Magazine, Posters", preuzeto 24. 7. 2020, https://digitalcollections.nypl.org/ collections/magazine-posters\#/?tab=about.
} 
првих неколико су: жене, коњи, одећа и одевање и др. (Сл. 3). По карактеристици име поред Едварда Пенфилда као аутора, могу се пронаћи имена особа на плакатима нпр. Марк Твен (1835-1910), Џорџ Вашингтон (1732-1799) и др. За потребе овог рада, међу јавно доступним плакатима према категорији „читање“ пронађено је 13 јединица грађе које и визуелно одговарају задатом критеријуму, међу којима има дупликата. Дакле, у овој збирци се због постојања дефинисане категорије, филтрирање плаката по теми показало практично значајним за сам ток истраживања.

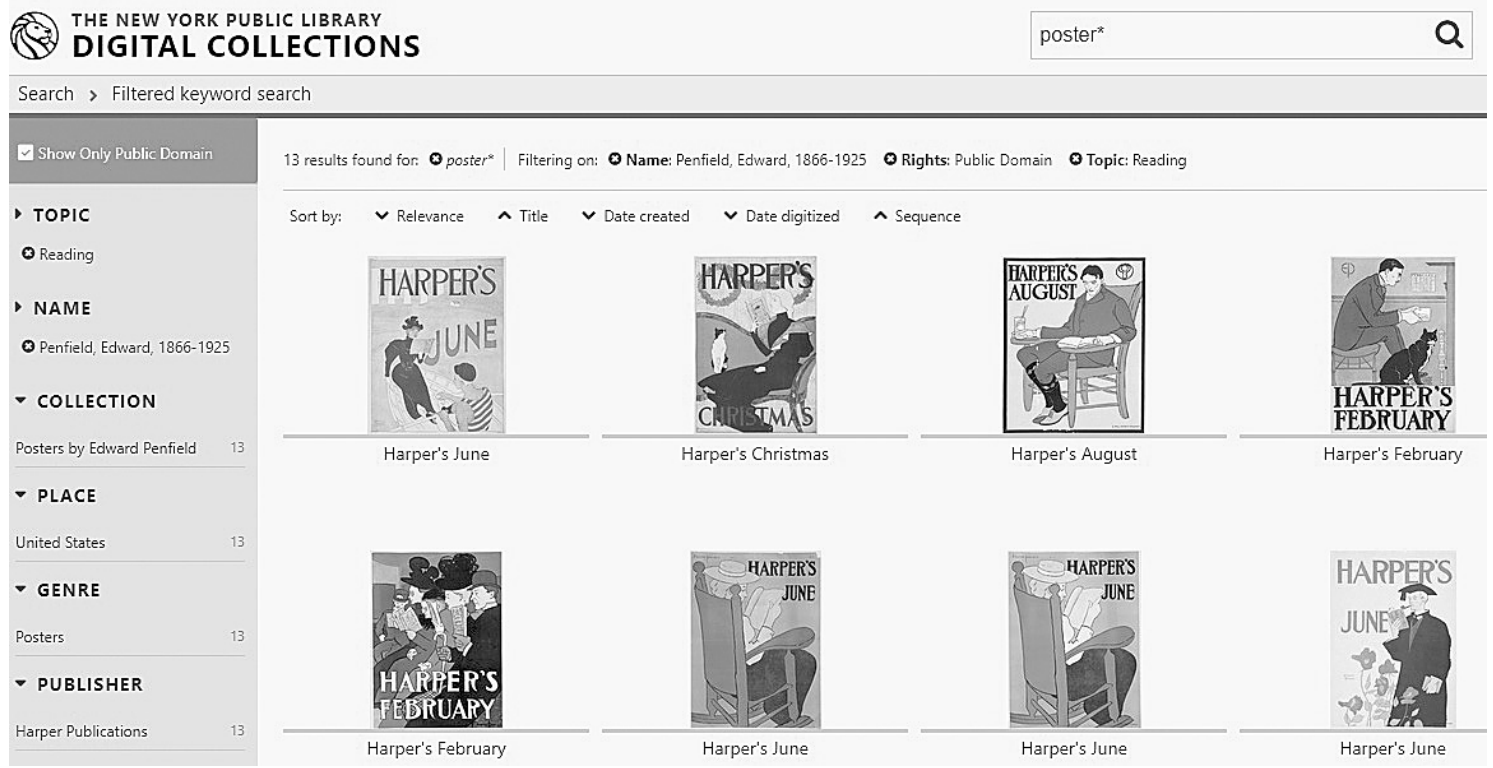

Слика 3. Збирка плаката Едварда Пенфилда, филтери јавна доступност и тема

Одабрани плакат из ове збирке послужиће за илустрацију додатних информација и опција које постоје у датом окружењу. Наиме, на веб-страници плаката као јединице дигиталне грађе, налазе се важне информације и могућности за његово коришћење (Сл. 4). На почетку је уочљива слика плаката са пратећим алатом који омогућава њено зумирање, ротирање или штампање. Он носи наслов Harper's February, нацртао га је Едвард Пенфилд (1866-1925) за издавачку кућу Harper's у Америци 1895. године. Налази се у оквиру Одељења уметности, штампе и фотографија Мириам и Ире Д. Валах: збирке уметности и архитектуре. Оригиналан постер је литографија димензија 49 х 35,5 cm и претражив је по тематској категорији "читање". Приказани плакат има дозволу за коришћење и за потребе приказивања преузет је у виду слике стандардног формата (760px), а за потребе цитирања преузет је понуђени облик у Чикаго стилу. ${ }^{23}$ Адреса веб-странице плаката може се поделити на друштвеним мрежама Твитер, Пинтерест или Фејсбук, са навођењем ID броја. ${ }^{24}$ Све релевантне датуме (1866: рођење аутора, 1895: година издања, 1925: смрт аутора, 2016: дигитализација и 2020: година када је јединица пронађена) могуће је видети обележене на временској линији којом је представљен његов животни циклус. Плакат може да се погледа заједно са осталим плакатима из збирке користећи опцију „види као књигу”, као да се листа књига. Он је видљив и на другим платформама са којима је успостављена веза. То су Дигитална јавна библиотека Америке и Каталог

23 Постоји напомена да је прецизност цитата потребно накнадно проверити

${ }_{24}$ На Сл. 1. дат је пример дељења дигиталне јединице на Инстаграму. 
Њујоршке јавне библиотеке. 3бог различитог односа према ауторским правима у другим земљама, приликом навођења извора препоручљиво је ставити напомену Из Њујоршке јавне библиошеке и навести веб-адресу плаката.

Дакле, из наведеног се може рећи да веб-страница јединице грађе представља богат извор информација које ће кориснику послужити за даљу употребу плаката: преузимање, опис, класификацију, цитирање или дељење. У библиотечком смислу, значајна је његова повезаност са каталошким описом у електронском каталогу Библиотеке (мада је он врло штур и непрегледан), као и упитна могућност преузимања готовог и прецизног цитата у неколико стилова.

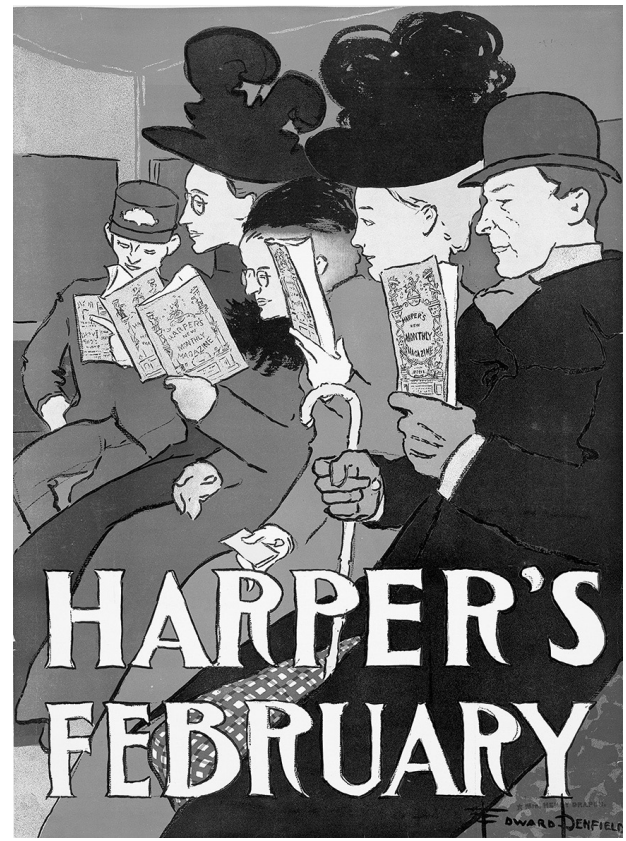

Слика 4. Плакат Едварда Пенфилда из 1895. у издању Harper's February25

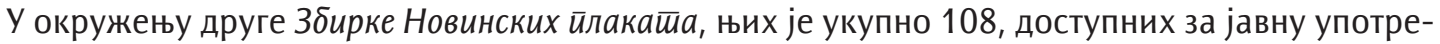
бу, који датирају из периода 1893-1897. године. Оригинални плакати су постављени и увезани у Њујоршкој јавној библиотеци 1939. године. Сачињена је од плаката из различитих америчких новинских издања, највише из: The Boston Sunday Herald, The Cleveland leader, The New York Sunday herald, The New York Sunday world и др. Њихова претрага није могућа по именима аутора, али је тематика претражива по 18 различитих категорија. Сходно мотивима овог рада, изабрана је тема књиї и иишање која даје само два плаката из дневних новина Boston Sunday herald. Међутим, у претрази без коришћења филтера, уочени су плакати (њих 15) на којима је визуелно представљено читање, али су категорисани према другим аспектима, или нису уопште категоризовани (Сл. 5).

Из наведеног се може рећи да ова збирка није довољно прецизно обрађена по карактеристикама аутор и тема, тако да у случају да корисник изабере неки од плаката, недостајаће му важан податак ауторства. Додатно, за преглед плаката унутар збирке, постојеће опције за сортирање по наслову, датуму креирања или датуму дигитализације немају никакву улогу. 3бог

\footnotetext{
25 The Miriam and Ira D. Wallach Division of Art, Prints and Photographs: Art \& Architecture Collection, "Harper's February", The New York Public Library Digital Collections, 1895, preuzeto 11. 9. 2020, http://digitalcollections.nypl.org/items/510d47dc -48ae-a3d9-e040-e00a18064a99.
} 
Јовин ). „Мотив читања на плакатима с краја 19. века у Дигиталним збиркама Њујоршке јавне библиотеке“, 93-102

споменуте мањкавости каталогизације, у процесу трагања за конкретним визуелним мотивом без коришћења филтера, кориснику би већу практичну вредност пружиле опције за увећавање плаката и тиме допринеле лакшем уочавању детаља. Напоменимо и то да се на споменутој веб-страници сваког плаката, опција „види као књигу”, која омогућава добар приказ и прелиставање већег броја из заједничке збирке показала непоузданом, јер се у неким случајевима нису могли видети сви плакати.
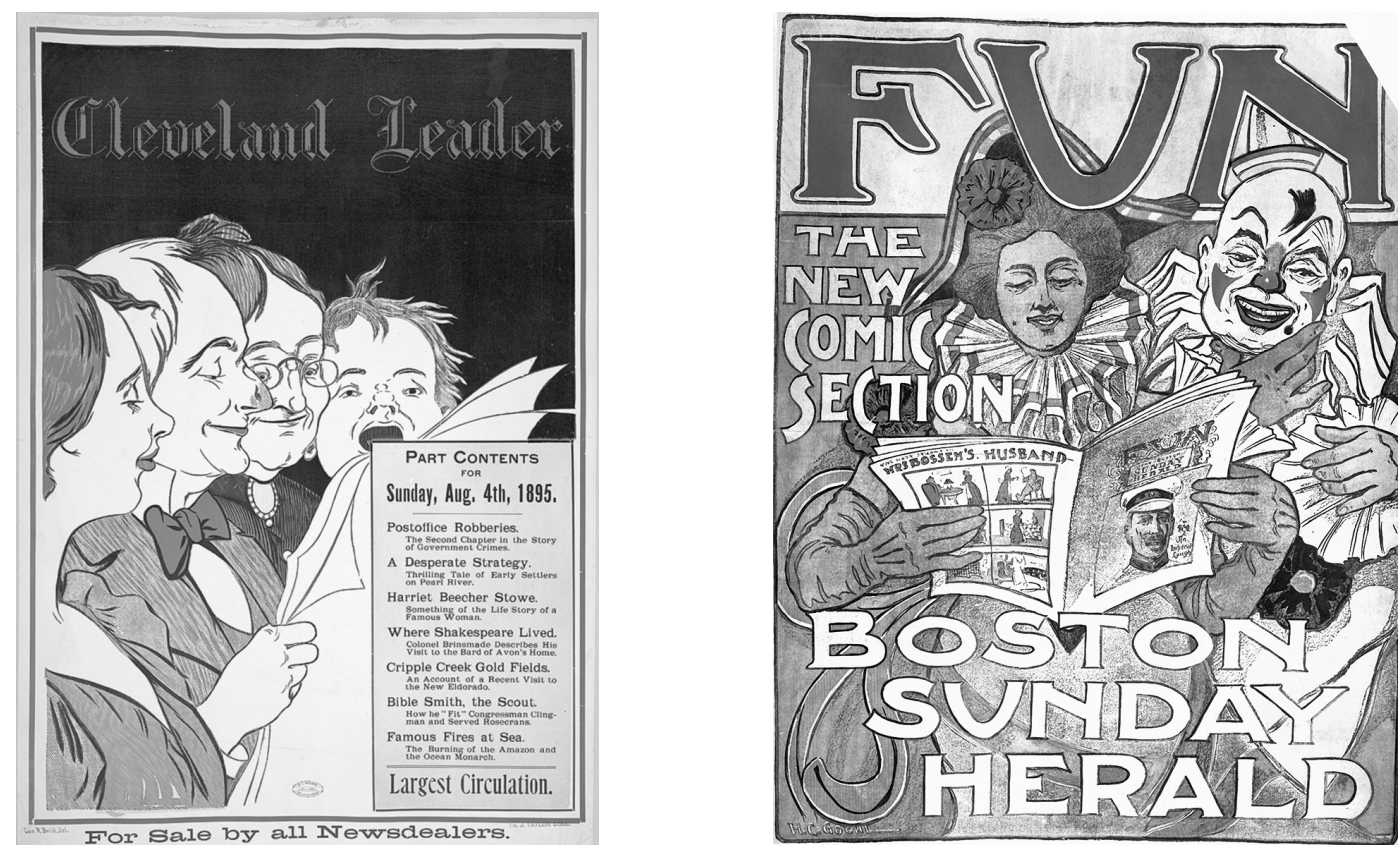

Слика 5. Чит̆аюе није видљиво у претрази јер плакат: нема тему

има тему кловнови

Cleveland leader. Sunday, Aug. 4th, 1895. ${ }^{26}$

Fun the new comic section. Boston Sunday herald ${ }^{27}$

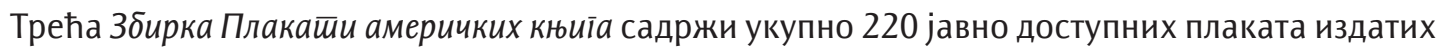
у периоду 1895-1911. године. Оригинали су постављени и увезани у Њујоршкој јавној библиотеци 1939. године. Што се филтера тиче, плакати су по теми разврстани у две категорије: постери, амерички и издавачка индустрија. Идентификовано је пет имена аутора. По карактеристици жанра постоје три категорије: рекламе, плакати у књигама и часописима и плакати. Међутим, претрага по свим филтерима даје за резултат све плакате, што није од велике помоћи ни значаја за дато истраживање. Прегледом збирке без употребе филтера уочен је мотив читања на шест плаката, без познатих аутора, што умањује њихов значај у избору.

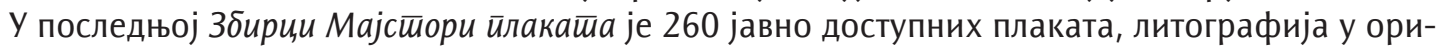
гиналу. Представљају издања париске издавачке куће Imprimerie Chaix из периода 1896-1900.

\footnotetext{
${ }^{26}$ The Miriam and Ira D. Wallach Division of Art, Prints and Photographs: Art \& Architecture Collection, "Cleveland leader. Sunday, Aug. 4th, 1895", New York Public Library Digital Collections, preuzeto 11. 9. 2020, http://digitalcollections.nypl.org/ items/510d47e2-8f3e-a3d9-e040-e00a18064a99.

27 The Miriam and Ira D. Wallach Division of Art, Prints and Photographs: Art \& Architecture Collection, "Fun the new comic section. Boston Sunday herald", The New York Public Library Digital Collections, 1893-1897, preuzeto 11. 9. 2020, http://digitalcollections.nypl.org/items/510d47e2-8f31-a3d9-e040-e00a18064a99.
} 
године. Збирка има кратак опис: „Мајстори плаката: месечна публикација која садржи репродукције најлепших илустрованих плаката великих уметника, француских и страних." ${ }^{28}$ Плакати су груписани у три подзбирке и претраживи по 46 различитих тематских категорија. Категорију „читање“ има само један. Прегледом целокупне збирке без филтера и адекватних алата за увећање и посматрање детаља, који кориснику додатно одузима време, пронађено је само четири који одговарају траженом критеријуму. Изабрани плакати на француском, енглеском и данском језику имају познате ауторе. Према карактеристици име, поред назива издавача постоји и око 100 имена аутора.

\section{Коментари и запажања}

Искуство коришћења портала Дигиталних збирки Њујоршке јавне библиотеке показало је важност постојања једног свеобухватног и кориснику прилагођеног начина функционисања виртуелног окружења. Такође је значајно и истицање конкретних потреба корисника за једноставним приступом грађи и пратећим апликацијама, лако доступним и обједињеним упутствима за њено коришћење, прецизним претраживањем и прилагођеним приказом материјала.

Из угла корисника који на почетној веб-страници портала по први пут приступа претраживачу, потребне су различите информације и упутства за претраживање, који су, како се показало, скривени и разуђени иза слабо уочљиве ознаке „і". Поред детаља везаних за претраживање и преузимање грађе, ту се могу пронаћи информације о дозволама за коришћење, метаподацима и самој платформи, као и везама са другим порталима. За додатне информације потребно је следити многобројне линкове, што додатно оптерећује корисника.

По свом допадљивом дизајну и многобројним апликацијама за визуелизацију, анимацију, игру, манипулацију са географским картама, заиста се може уважити мишљење Дена Коена да је у питању „једна од најиновативнијих дигиталних библиотека икад." 29 Међутим, и у овом случају не постоји директан приступ наведеним садржајима са почетне веб-странице портала, него су све релевантне информације, преко линкова доступне на веб-сајту Библиотеке.

Што се претраге грађе тиче, иако је она могућа на различитим нивоима, додатно побољшана опцијама за сортирање и визуелни преглед, ипак има и нека ограничења. Показало се да је визуелни мотив тешко идентификовати путем класификације и метаподатака, па је претрагу потребно изводити на вишем и ширем нивоу, а тиме она постаје компликованија и дуготрајнија. На овакву мањкавост скреће пажњу и Еди Вудворд, критикујући процес дигитализације у библиотекама и указујући на честу појаву да је од примарног значаја да дигиталне јединице буду доступне, а од секундарног да буду квалитетно описане помоћу метаподатака, чиме постају и мање приступачне. ${ }^{30}$ У описаном процесу претраживања мотива читања, најрелевантнијом се показала претрага појма плакат на нивоу збирки, док би на нивоу појединачних плаката кључну улогу одиграло доследно постојање прецизно дефинисане тематске категорије. Шта више, за потребе истраживања неопходни су и подаци о аутору, издавачу, месту и др., што би у идеалном случају подразумевало повезаност сваког плаката са детаљним каталошким записом. Додатну препреку у процесу трагања за конкретним визуелним мотивом кориснику прави немогућност увеличавања плаката унутар збирке, као и непоуздана опција за листање плаката у виду књиге.

\footnotetext{
28 The New York Public Library, "Digital Collections: Les Maîtres de l'affiche: publication mensuelle contenant la reproduction des plus belles affiches illustrées des grands artistes, français et étrangers", preuzeto 24. 7. 2020, https://digitalcollections.nypl.org/ collections/les-matres-de-laffiche-publication-mensuelle-contenant-la-reproduction-des-plus\#/?tab=filter\&scroll=3.

${ }^{29}$ NYPL Labs, preuzeto 2. 9. 2020, https://www.nypl.org/collections/labs.

30 Eddie Woodward, "Metadata for Image Collections Inverse proportions: The quantity vs. quality conundrum", American Libraries, July 21st 2014, preuzeto 2. 9 2020, https://americanlibrariesmagazine.org/2014/07/21/metadata-for-image-collections/.
} 
Ипак, и поред издвајања времена за упутства, затим неупотребљивих филтера, слабости у класификацији и претраживању, као и проблема адекватног приказа грађе, од укупно 700 плаката распоређених у четири јавно доступне збирке, са портала се може направити избор од 40 који испуњавају задати визуелни критеријум. Према доступним метаподацима, ради се већином о плакатима (литографијама) из америчке периодике с краја 19. века, делима Едварда Пенфилда и других, већином непознатих аутора. У даљем процесу, они се могу користити за потребе истраживања, едукације, промоцију на друштвеним мрежама, креирање уметничких дела и на многе друге начине.

У крајњем случају, суштина портала и јесте у томе да се на неки начин може испричати и поделити прича о одабраној дигитализованој грађи и тиме, у ширем смислу, представити културно наслеђе садржано у богатом фонду библиотеке. Да би се остварила тако замишљена мисија, неопходно је, поред бројности грађе, корисницима портала омогућити што једноставнији и прегледнији приступ и обезбедити што прецизнију претрагу.

\section{Литература и извори:}

1. Foo, Brian, remix by. A public domain of NYPL Labs. Preuzeto 2. 8. 2020. http://publicdomain.nypl. org/pd-visualization/.

2. Giraldo, Mauricio, remix by. "Mansion Maniac". Public domain: Apartment Houses of the Metropolis collection. Preuzeto 24. 7. 2020. http://publicdomain.nypl.org/mansion-maniac/.

3. Hadro, Josh. "Manufacturing Impact: Why We Digitize". New York Public Library, November 6th 2017. Preuzeto 24. 7. 2020. https://www.nypl.org/blog/2017/11/06/manufacturing-impact-digitize.

4. Hadro, Josh. "NYPL Digital Collections Platform: An Introduction". New York Public Library, January 21st 2015. Preuzeto 2. 8. 2020. https://www.nypl.org/blog/2015/01/21/ digital-collections-platform-intro.

5. Lampasone, Lauren. "\#nyplremix: Get Creative With the Public Domain". New York Public Library, January 6th 2016. Preuzeto 24. 7 2020, https://www.nypl.org/blog/2015/01/06/ creativity-public-domain.

6. NYPL Labs. Preuzeto 2. 9. 2020. https://www.nypl.org/collections/labs.

7. Stereogranimator. Preuzeto 2. 8. 2020. http://stereo.nypl.org/.

8. The Miriam and Ira D. Wallach Division of Art, Prints and Photographs: Art \& Architecture Collection "Cleveland leader. Sunday, Aug. 4th, 1895". New York Public Library Digital Collections. Preuzeto 11. 9. 2020, http://digitalcollections.nypl.org/items/510d47e2-8f3e-a3d9-e040-e00a18064a99.

9. The Miriam and Ira D. Wallach Division of Art, Prints and Photographs: Art \& Architecture Collection. "Fun the new comic section. Boston Sunday herald". The New York Public Library Digital Collections, 1893-1897. Preuzeto 11. 9. 2020. http://digitalcollections.nypl.org/ items/510d47e2-8f31-a3d9-e040-e00a18064a99.

10. The Miriam and Ira D. Wallach Division of Art, Prints and Photographs: Art \& Architecture Collection. "Harper's February". The New York Public Library Digital Collections, 1895. Preuzeto 11. 9. 2020. http://digitalcollections.nypl.org/items/510d47dc-48ae-a3d9-e040-e00a18064a99.

11. The New York Public Library. "Are you always on the lookout for your next great read?". Instagram, 15. 9. 2020. https://www.instagram.com/p/CC04QBmJW3s/.

12. The New York Public Library. Building inspector. Kill time. Make history. Preuzeto 2. 8. 2020. http://buildinginspector.nypl.org/.

13. The New York Public Library. "Digital Collections". Preuzeto 24. 7. 2020. https://digitalcollections. nypl.org/. 
Јовин ). „Мотив читања на плакатима с краја 19. века у Дигиталним збиркама Њујоршке јавне библиотеке“, 93-102

14. The New York Public Library, “Digital Collections: Les Maîtres de l'affiche: publication mensuelle contenant la reproduction des plus belles affiches illustrées des grands artistes, français et étrangers". Preuzeto 24. 7. 2020. https://digitalcollections.nypl.org/collections/les-matres-de-laffiche-publication-mensuelle-contenant-la-reproduction-des-plus\#/?tab=filter\&scroll=3.

15. The New York Public Library. "Digital Collections: Magazine, Posters". Preuzeto 24. 7. 2020. https:// digitalcollections.nypl.org/collections/magazine-posters\#/?tab=about.

16. Woodward, Eddie. "Metadata for Image Collections Inverse proportions: The quantity vs. quality conundrum". American Libraries, July 21st 2014. Preuzeto 2. 9 2020. https://americanlibrariesmagazine. org/2014/07/21/metadata-for-image-collections/.

\title{
Reading as a Motif on Posters from the End of the $19^{\text {th }}$ Century in the New York Public Library Digital Collections
}

\begin{abstract}
Summary
In the era of digitalization, an increasing amount of material is becoming available to the users of the Web. Accordingly, for the purpose of collecting material for exhibitions, preparing lectures, researching the history of a nation or the life of a particular painter, writing a blog or posting a tweet, the necessary illustrations, photographs or manuscripts can be found on portals such as Europeana, the Digital Public Library of America (DPLA), and many others. This paper aims to present the process of searching for material related to the selected topic, i.e. reading as a motif on the posters in the New York Public Library Digital Collections, given that the part of the digitized material is in public domain. In addition to the numerous possibilities of using and sharing material for users of the portal, the searching process difficulties were also pointed out. The purpose of the paper is to bring the functioning of a portal with digitized material closer to readers from the point of view of librarians as users, to point out the problems of the processing, visibility, and accessibility of this material, as well as to encourage librarians to come up with ideas and solutions for creating more attractive, coherent, and user-friendly portals.
\end{abstract}

Keywords: New York Public Library (NYPL), portal, digitized material, public availability, search, poster, reading, classification, metadata, sharing, transparency, user-friendliness 
